\title{
Cervical Intradural Glass Fragment: A Rare Cause of Neuropathic Pain
}

\section{Nöropatik A ğrının Nadir Bir Nedeni Olarak Intradural Cam Parçası}

\author{
Mehmet Osman AKCAKAYA, Yavuz ARAS, Ali Guven YORUKOGLU, Cem OVALIOGLU, Altay SENCER \\ Istanbul University, Istanbul Faculty of Medicine, Department of Neurosurgery, Istanbul, Turkey \\ Presented In: Society of Nervous System Surgery, VI. Scientific Congress, 28-31 October, 2010, Marmaris, Turkey
}

Correspondence address: Mehmet Osman AKCAKAYA / E-mail: moakcakaya@gmail.com

\begin{abstract}
Intradural foreign bodies after penetrating injuries are seen very rarely. Limited number of cases of glass fragments in the spinal canal were reported previously. Migration of foreign bodies and delayed onset of neurological symptoms due to foreign bodies were also reported. In this report a 33-year-old male patient was presented, who had penetration of glass fragments through oropharyngeal mucosa in to the spinal canal after crashing into a glass door. Glass fragment, which migrated through an unusual route, and reached cervical spinal intradural space, caused neuropathic pain with radicular symptoms, 21 years after the initial injury. This case report emphasize that after penetrating injuries of spine, foreign bodies may remain silent until the patient became symptomatic years after the initial injury and these foreign bodies may migrate to extreme distant and unexpected locations in the central nervous system.
\end{abstract}

KEYWORDS: Intradural foreign bodies, Migration, Glass, Neuropathic pain

öz

Delici-kesici yaralanmalar sonrası intradural yabancı cisimler oldukça nadirdir. Omurilik kanalı içerisinde yabancı cisim olarak cam parçası görülmesi ve bunun yer değiştirerek geç dönemde semptomlara yol açması daha da nadirdir. Bu çalışmada, omurilik kanalı içerisinde yer değiştiren cam parçasına bağlı geç dönemde şikayetleri ortaya çıkan 33 yaşında bir erkek hasta sunulmuş; nadir görülmesi ve genel tecrübeye katkıda bulunmak amacıyla tartışıması amaçlanmıştır. Hastanın 21 yıl önce cam kapıya çarpma sonrası ağız mukozasına cam parçaları saplandığı öğrenilmiş ve bu parçaların servikal spinal intradural mesafeye ulaşarak hastada radiküler bulgularla birlikte nöropatik ağrıya sebep olduğu görülmüştür. Omuriliğin delici-kesici yaralanmalarında nadir de olsa yabancı cisimlerin omurilik kanalında kalabileceği ve bunların hem medüller hem de radiküler bulgulara yol açabileceği unutulmamalıdır. Orofarinks mukozasının delici-kesici yaralanmalarında da yabancı cisimlerin omurilik kanalına ulaşarak, erken dönemde veya yer değiştirme sonrası geç dönemde klinik bulgular ortaya çıkartabileceği gözden kaçırılmamalıdır.

ANAHTAR SÖZCÜKLER: İntradural yabancı cisim, Migrasyon, Cam, Nöropatik ağrı

\section{INTRODUCTION}

Penetrating spinal injuries most commonly occur due to missile, sharp knifelike objects and rarely due to glass $(4,15$, $17,18,21)$. However, cases with intradural foreign bodies after penetrating injuries except missile injuries are very rare $(5,8,9$, $11,24)$. There are only a few reported cases of glass fragments in the spinal canal $(4,13,14,22)$. Spontaneous migration of the foreign bodies in the spinal canal have been reported previously $(2,3,10,19)$. There are only a limited number of cases with late onset clinical symptoms due to intraspinal foreign bodies $(3,6,9,13,14,26)$. Herein a case of 33-year-old man was reported with a cervical intradural glass fragment, which migrated in the spinal canal and became symptomatic 21 years after the initial trauma.

\section{CASE REPORT}

A 33-year-old male patient was admitted with pain and dysaesthesia on his left arm for 10 years. His complaints had become more severe in the last 6 months and in addition to that he noticed a new onset of weakness on his left arm. There was no history of recent trauma. From his history it was found out, that 21 years ago he had crashed into a glass door and glass fragments had penetrated through his mouth into the oropharyngeal mucosa. Right after the injury he was operated by an ear-nose-throat surgeon in order to clean the fragments. The patient was told that fragments were totally removed, but no further radiological evaluation had been made after the surgery.

Neurological examination revealed a 4/5 weakness of left biceps, triceps and wrist extension, dysaesthesia on C4-C5 dermatomes. Antero-posterior and lateral plain radiographs of cervical spine were normal. Computed tomography (CT) and magnetic resonance imaging (MRI) scans of cervical spine revealed a foreign body, consistent with glass, in the spinal canal at $C 5$ level on the left side (Figure1A,B, 2A,B). Left $C 4$ and $C 5$ laminectomy was performed and the epidural space 
was explored. There was no evidence of a foreign body in the epidural space. The dura was opened and a glass fragment of $14 \times 6 \mathrm{~cm}$ size with $3 \mathrm{~mm}$ thickness, compressing the medulla and rootlets was found (Figure 3 ). There was no sign of arachnoiditis, and only a minimal reactional thickening of C4
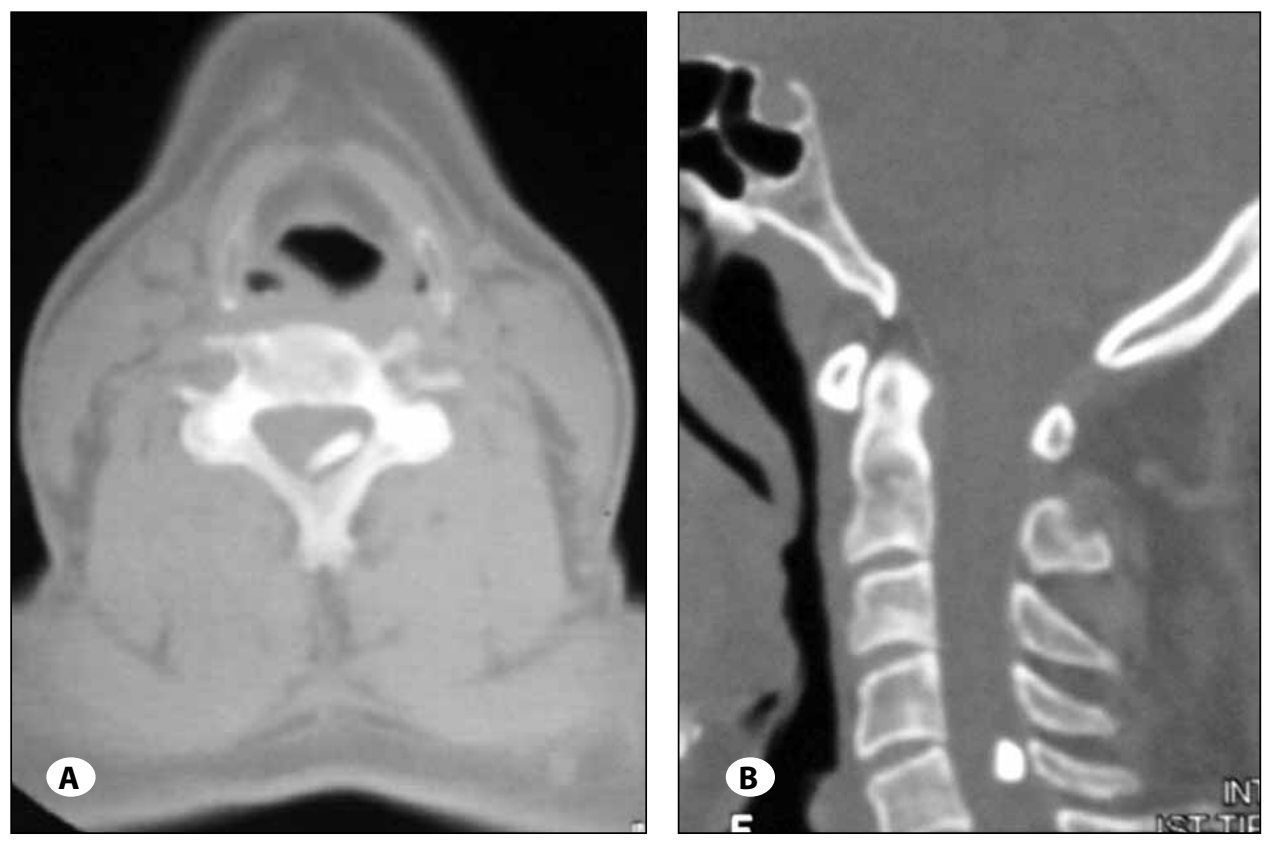

Figure 1: Axial (A) and sagittal (B) CT scans showing a high density object at C4-5 level in the spinal canal. root was seen. In the early postoperative period the patient experienced significant pain relief. Two months after the surgery the patient had no complaints and his neurological examination was normal.
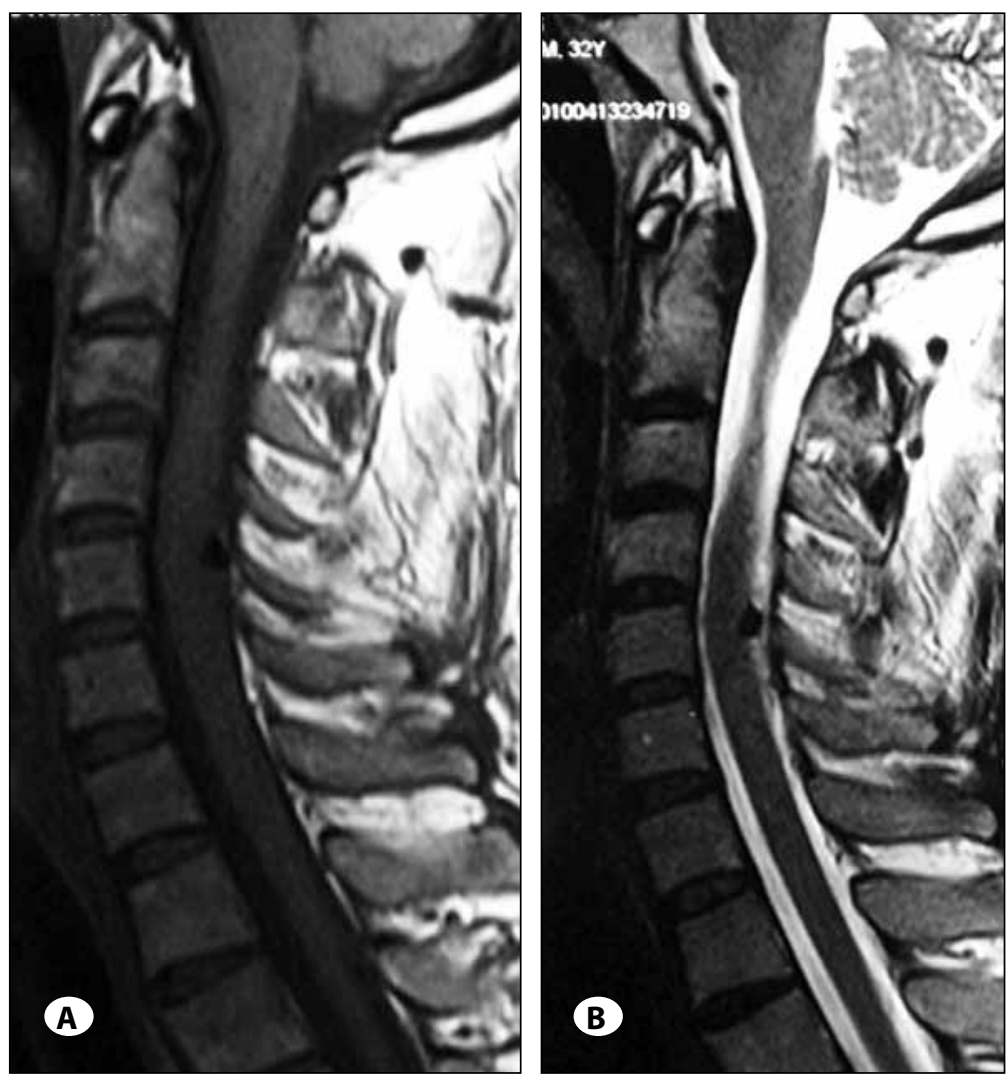

Figure 2: T1-weighted (A) and T2 -weighted (B) sagittal MRI scans shows a hypointense lesion behind the spinal cord. 


\section{DISCUSSION}

Penetrating injuries of the spinal cord are relatively infrequent compared to blunt trauma. They mostly occur due to missile injuries, rarely to glass or wood fragment $(1,12,16)$. Intradural foreign bodies due to these injuries are extremely rare. Common foreign bodies are bullets or metallic fragments in missile and rarely rock and earth pieces in mine injuries (5). Intraspinal glass fragments have been reported only in a limited number of cases $(13,14,22)$. Foreign bodies that stay silent for months or years until they cause neurological symptoms due to migration in the spinal canal are even rarer $(6,9,11,13,14,22,25)$.

Traditionally surgery is indicated because of risk of toxicity if the foreign body is made of lead or copper even when there are no progressive neurological symptoms. For sharp foreign bodies and/or retained canal fragments surgery is indicated immediately after trauma to prevent neurological deterioration independent from the spinal level of injury (23). In our case the time interval between the initial trauma and the onset of neurological symptoms was relatively long at 21 years. Oertel et al. reported a case of a glass fragment in the spinal canal, which became symptomatic 12 years after the injury, probably because of degenerative changes of the spine (14). We want to underline that a previously asymptomatic foreign body in the spinal canal may became symptomatic and this is independent from the length of the asymptomatic time period. New symptoms may occur due to compression to neural elements even years after the injury. It has been described that a subarachnoidal foreign body may cause radicular symptoms (10). Our case also presented with radicular symptoms, but it has to be considered that these foreign bodies might present also with myelopathy $(9,25)$.

The route of migration of the glass fragment was also extraordinary in this case. Spontaneous migration of foreign bodies in the spinal canal has been previously described $(3$, 10, 19).

The migration risk is higher for injuries below the T12 spinal level, but cranial foreign bodies might also migrate to the spinal canal (7). Transoral penetration of foreign bodies to the spinal canal are extremely rare and this kind of injury happens more commonly in Japan due to penetration of half-split chopsticks into the mouth (20).

Taniura et al. published an interesting case where the chopstick penetrated transorally between the dens and basion, and reached the subarachnoid space at the medulla oblongata (20). The trajectory of the foreign body was different in our case, but it demonstrates that transorally penetrated foreign bodies might reach the central nervous system. In this case, the glass fragment entered from patient's mouth and crossed through the ororpharyngeal mucosa. It probably passed through the anterior longitudinal ligament and entered the spinal canal via the C2-3 disc interspace, between the vertebral arteries without causing any vascular damage. Then it migrated from the anterior subarachnoidal space to the posterior subarachnoidal space, until it reached the C4-5 vertebra level, where it became symptomatic. The asymptomatic migration can be explained by the wider diameter of the upper cervical spinal canal. The lordotic angle at the C4-5 level did not allow the glass fragment's further migration to the lower cervical spine. It must be considered foreign bodies might be found in unexpected locations within spinal cord irrespective of the entrance wound.

Plain radiographs and $\mathrm{CT}$ are effective methods to investigate both metallic and glass fragments. In case of a metallic foreign body, MRI can cause damage in the neural structures. On the other hand, MRI might provide the most valuable and precise data about the location of glass fragments. In our case it was expected that the glass fragment would be found epidurally, and the $\mathrm{CT}$ scan demonstrated the glass fragment adjacent to lamina. However, careful evaluation of the MRI scan showed that the glass fragment was located intradurally. Considering the size of the intradural glass fragment $(14 \times 6 \times 3 \mathrm{~mm})$ in our case, it is very interesting that the patient remained asymptomatic for such a long time period.

It is important to underline foreign bodies may remain silent after penetrating injuries of spine until the patient becomes symptomatic years after the initial injury and foreign bodies may migrate to extreme distant and unexpected locations in the central nervous system.

\section{REFERENCES}

1. Adornato DC Jr, Collis JS Jr: Stab wounds of the spinal cord. Int Surg 57:147-150, 1972

2. Arasil E, Tascioglu AO: Spontaneous migration of an intracranial bullet to the cervical spinal canal causing Lhermitte's sign. Case report. J Neurosurg 56:158-159, 1982

3. Avci SB, Acikgoz B, Gundogdu S: Delayed neurological symptoms from the spontaneous migration of a bullet in the lumbosacral spinal canal; case report. Paraplegia 33:541-542, 1995

4. Baghai $P$, Sheptak PE: Penetrating spinal injury by a glass fragment: Case report and review. Neurosurgery 11:419-422, 1982

5. Duz B, Cansever T, Secer HI, Kahraman S, Daneyemez MK, Gonul E: Evaluation of spinal missile injuries with respect to bullet trajectory, surgical indications and timing of surgical intervention: A new guideline. Spine 33(20): E746-753, 2008

6. Farooq M, Dhar S, Butt MF: Late onset neurogenic claudication in a case of metallic intradural ballistic fragment. Joint Bone Spine 74:187-189, 2007

7. Ilkko E, Reponen J, Ukkola V, Koivukangas J: Spontaneous migration of foreign bodies in the central nervous system. Clin Radiology 53:221-225, 1998

8. Jeffery JA, Borgstein R: Case report of a retained bullet in the lumbar spinal canal with preservation of cauda equina function. Injury 29:724-726, 1989

9. Jones DF, Woosley RE: Delayed myelopathy secondary to retained intraspinal metallic fragment. J Neurosurg 55: 979-982, 1981 
10. Karim NO, Nabors MW, Golocovsky M, Cooney FD: Spontaneous migration of a bullet in the spinal subarachnoid space causing delayed radicular symptoms. Neurosurg 18: 97-100, 1986

11. Kuijen JM, Herpers MJ, Beuls EA: Neurogenic claudication, a delayed complication of a retained bullet. Spine 22:910-914, 1997

12. Lipschitz R: Associated injuries and complications of stab wounds of the spinal cord. Paraplegia 5:75-82, 1967

13. Miyazaki Y, Inaba K: Transfixion of cervical cord by a glass fragment-report of a case. No Shinkei Geka 4:799-803, 1976 (Japanese)

14. Oertel MF, Kreitschmann-Andermahr I, Ryang YM, Gilsbach, Korinth MC: The awakened intraspinal glass shard. Acta Neurochir 151: 99-101, 2009

15. Opel DJ, Lundin DA, Stevenson KL, Klein EJ: Glass foreign body in the spinal canal of a child: Case reportand review of the literature. Pediatr Emerg Care 20:468-472, 2004

16. Pal D, Timothy J, Marks P: Penetrating spinal injuries with wooden fragments causing cauda equina syndrome: Case report and literature review. Eur J Spine Suppl 5:574-577, 2006

17. Rubin G, Tallman D, Sagan L, Melgar: An unusual stab wound of the cervical spinal cord: A case report. Spine 26:444-447, 2001
18. Simpson RK Jr, Venger BH, Narayan RK: Treatment of acute penetrating injuries of the spine: A retrospective analysis. J Trauma 29:42-46, 1989

19. Sorensen N, Krauss J: Movement of hemostatic clips from the ventricles through the aqueduct to the lumbar spinal canal. Case report. J Neurosurg 74:143-146, 1991

20. Taniura S, Tatebayashi K, Akatsuka K, Takenobu A, Kamitani $\mathrm{H}$, Yokota M, Watanabe T: Transoral penetration of a half-split chopstick between the basion and the dens. Am J Neuroradiol 25: 871-872, 2004

21. Thakur RC, Khosla VK, Kak VK: Non-missile penetrating injuries of the spine. Acta Neurochir (Wien) 113:144-148, 1991

22. Topliff EE, Daly JS: Accidental puncture of the cerebrospinal canal. Can Med Assoc J 24:836-838, 1931

23. Waters RL, Sie IH: Spinal cord injuries from gunshot wounds to the spine. Clin Ortop Relat Res 408:120-125, 2003

24. Williams DT, Chang DL, DeClerk MP: Penetrating spinal cord injuries with retained canal fragments. CJEM 11:172-173, 2009

25. Wolf SM: Delayed traumatic myelopathy following transfixion of the spinal cord by a knife blade. Case report. J Neurosurg 38:221-225, 1973

26. Wu WQ: Delayed effects from retained foreign bodies in the spine and spinal cord. Surg Neurolog 25:214-218, 1986 